\title{
ID
}

\section{Roughness and Bonding Strength of Bioactive Apatite Layer on Dental Implants}

\author{
Joaquim Nogueras-Bayona, PhD, ${ }^{*}$ Francesc Javier Gil, PhD, $\uparrow$ Joan Salsench, PhD, $\neq$ Jordi Martinez-Gomis, PhD§
}

凤 he commercially pure titanium implants coated with a plasmasprayed hydroxyapatite layer are provided with bioactive surface properties and bone-bonding ability. ${ }^{1}$ However, the plasma-sprayed technique does not allow accurate control of the chemical composition and the crystallographic structure of the coating. As a result, the apatite layer is mechanically and chemically unstable, and it bonds weakly to the substrate. ${ }^{2}$

It was recently demonstrated by $\mathrm{Kokubo}^{3}$ that an in vitro bone-like apatite deposited on cp Ti could be induced by a chemical treatment. This apatite layer was integrated with the metallic substrates, and it did not have the problems associated with the plasma-spray technique. Kokubo's method showed that chemical treatment produced a uniform bioactive apatite layer on the surface of the titanium. ${ }^{4}$ The first purpose of this study was to evaluate how this new apatite layer changed the roughness of the implant surface.

The second purpose of this study was to examine the bonding strength of the hydroxyapatite layer obtained by chemical treatment to the $\mathrm{Ti}$ substrate. The results are discussed in comparison with those of plasmasprayed hydroxyapatite.

*Associate Professor, Section of Prosthodontics, Faculty of Dentistry, University of Barcelona, Barcelona, Spain. †Professor, Department of Materials Science and Metallurgy, ETSEIB, Technical University of Catalonia, Barcelona, Spain. łProfessor, Section of Prosthodontics, Faculty of Dentistry, University of Barcelona, Barcelona, Spain.

Denthodontics, Faculty of

ISSN 1056-6163/04/01302-001

Implant Dentistry

Volume 13 - Number 2

Copyright $\odot 2004$ by Lippincott Williams \& Wilkins

DOI: 10.1097/01.ID.0000127523.91195.BD
This study examined the roughness and bonding strength of the chemical-made apatite layer in comparison with the titanium surface and the plasma-sprayed apatite. Commercially pure titanium plates were heated and chemically treated to deposit crystalline apatite on their surface. The roughness of the titanium surface of the original samples and the apatite surface was analyzed by a roughness surface tester. A scratch test was used to compare the adhesion of the chemical apatite layer to the titanium with the adhesion of a plasma-sprayed layer. A dense bone-like apatite layer was formed on the surface of the titanium by a simple chemical method. The surface roughness test showed that

\section{Materials And Methods}

Specimen and Surface Treatment

Commercially pure titanium plates $(10 \times 10 \times 0.7 \mathrm{~mm})$ of grade II were used in this study. They were treated in accordance with the chemical treatment described by Takadama. ${ }^{5}$ The plates were treated with $0.5 \mathrm{M}$ $\mathrm{NaOH}$ aqueous solution at $60^{\circ} \mathrm{C}$ for 24 hours, washed with distilled water, and dried at $40^{\circ} \mathrm{C}$ for 24 hours. Subsequently, they were heated up to $600^{\circ} \mathrm{C}$ at a rate of $5^{\circ} \mathrm{C} /$ minute in an electric furnace, kept at $600^{\circ} \mathrm{C}$ for 1 hour, and then allowed to cool in the furnace. Finally, each treated titanium plate was completely soaked in $40 \mathrm{~mL}$ of simulated body fluid (SBF) at $37^{\circ} \mathrm{C}$ for 2 weeks. The samples were examined by an environmental scanning electron microscope (ESEM; Electroscan 2020; FEI, Oregon), which allows the observation of samples in wet the chemical apatite coating increased the roughness of the samples. The scratch test showed that the bonding strength of the chemical-made apatite coatings to the titanium substrate was higher than the plasma-sprayed apatite coatings. The apatite layer produced by chemical treatment did not show a lower roughness than the titanium substrate. This chemical apatite layer also bonded tighter to the titanium than the plasma-sprayed apatite. This chemically made apatite coating is expected to provide a long-term implant-bone fixation. (Implant Dent 2004;13:000O)

Key Words: biomaterials, apatite, titanium, scratch test

conditions with little need of handling. In fact, it has been possible to observe, in situ, the nucleation and deposition of the hydroxyapatite layer.

\section{Analyses of the Surface Roughness}

The roughness of the titanium surface of the original samples and the hydroxyapatite layer surface was analyzed by a Roughness Surface Tester (Mitutoyo Surftest SV-500; Mitutoyo, IL). Numerical values were produced by appropriate software (Surfpack v3.00). A Gaussian filter was used to exclude form and waviness. For numerical description, we used the $R_{a}$ descriptor parameter $\left(R_{a}\right.$ is the arithmetic mean of the departures of the roughness profile from the mean line, measured in micrometers; this parameter gives a good general description of height variations). Thirty-four roughness tests were done on 5 tita- 
TABLE 1. Roughness Test Conditions

\begin{tabular}{lc}
\hline & $\mathrm{Ti}$ \\
\hline Sample length $(\mathrm{mm})$ & 0.45 \\
Number of samples & 34 \\
Test length (mm) & 3.2 \\
Filter & Total tilt \\
Roughness profile & $\mathrm{R}_{\mathrm{a}}$ \\
Cutoff filter & Gaussiano \\
& Cutoff length $=0.21 \mathrm{~mm}$ \\
\hline
\end{tabular}

nium samples before the heat and chemical treatment and on 5 chemically made apatite layers. The sample length of each roughness test was 0.45 $\mathrm{mm}$. These roughness test conditions are shown in Table 1.

The ESEM was used to obtain an overall picture of the surface finish of the samples.

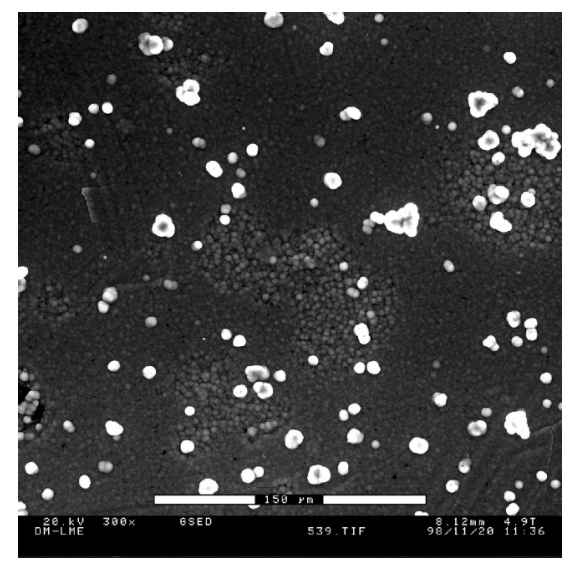

Fig. 1. Apatite structure and new nucleation on it.

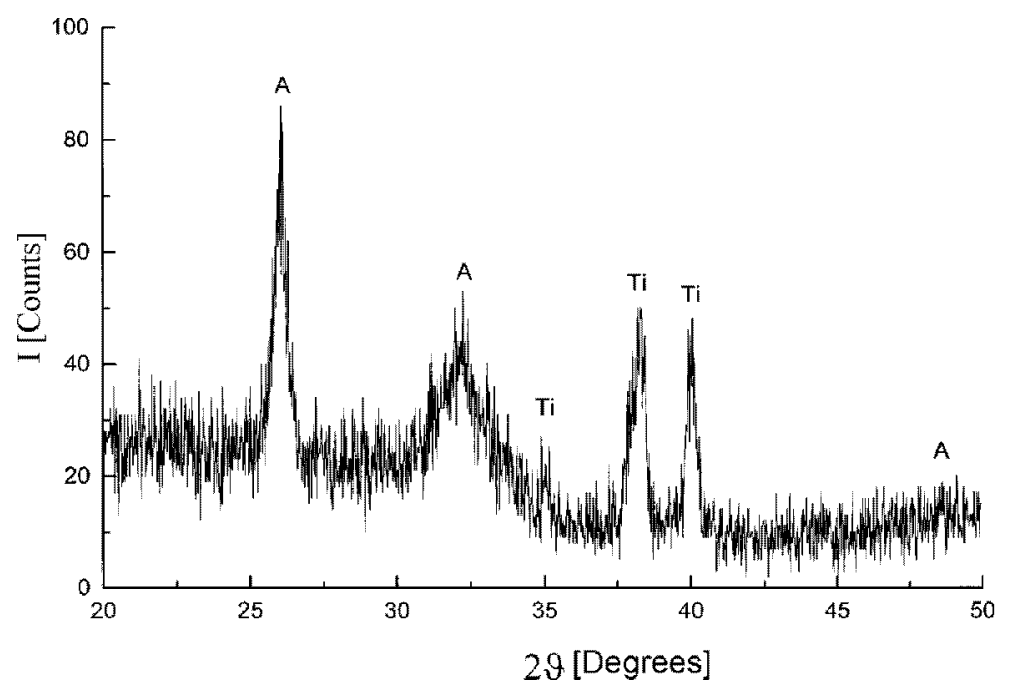

Fig. 2. X-ray spectrum of the layer deposited on the surface observing the peaks corresponding to the apatite ( $A$, apatite; Ti, titanium).

\section{Bonding Strength of Coating Layer to} Substrate

A scratch test was used (Fisher 320) to compare the adhesion of the chemical apatite layer to the $\mathrm{Ti}$ with the adhesion of the plasma-spray layer. We also compared their coating thickness. Five scratches were made on 5 samples coated with chemical apatite layer. Five scratches were also made on 5 reference samples coated with plasma-spray apatite. The length of each scratch was $2.4 \mathrm{~mm}$. The starting load was $2 \mathrm{~N}$ and the loading rate was $10 \mathrm{mN} / \mathrm{s}$. The horizontal scratch speed was $20 \mu \mathrm{m} / \mathrm{s}$.

\section{Statistical Analysis}

Data from scratch test and surface roughness measurements were analyzed using the SPSS package. $t$ test was used for intergroup differences among means (scratch test), and Wilcoxon test was used to test for intragroup differences (surface roughness). A 5\% level of probability was requested for statistical significance.

\section{Results AND Discussion Surface Roughness}

The apatite layer (Fig. 1) was obtained after treating the $\mathrm{Ti}$ samples with the chemical treatment that was described in the "Materials and Methods" section. The nature of this deposited layer was characterized by x-ray diffraction (Fig. 2). The spectrum shows a number of peaks at values around $25^{\circ}$ to $34^{\circ}$ and $46^{\circ}$ to $50^{\circ}$ corresponding to the apatite, whereas the titanate peaks were gradually disappearing. This result demonstrates the bioactive behavior of the chemicaltreated titanium surfaces. The apatite layer figures were obtained by the ESEM technique, because it allowed for the observation of the samples in the wet state. It was not necessary to manipulate the Ti samples interrupting the hydroxyapatite deposition. These factors mean that the samples can be reused and submerged again in SBF for the observation of the evolution of the apatite precipitation process.

The chemical bone-like apatite coating was expected to bond tightly to the $\mathrm{Ti}$, because it is gradual and chemically integrated with the substrate.

Figure 3 shows that the apatite layer grew uniformly along the titanium microsurface morphology along the Ti surface. That is to say, the chemical apatite coating does not have a smooth surface filling the titanium microporous surface.

The mean value of the roughness test $\left(R_{\mathrm{a}}\right)$ for the titanium surface was $0.07 \mu \mathrm{m}$ (standard deviation [SD],

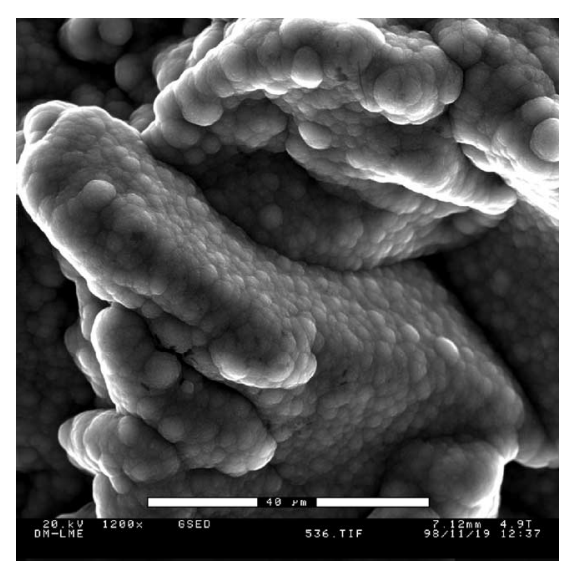

Fig. 3. Apatite layer uniformly deposited along the Ti surface. 
TABLE 2. Surface Roughness Test Results

\begin{tabular}{|c|c|c|c|c|}
\hline \multirow[t]{2}{*}{ Surface } & \multicolumn{2}{|c|}{ Titanium } & \multicolumn{2}{|c|}{ After Soaking in SBF } \\
\hline & Mean $\mathrm{R}_{\mathrm{a}}$ & Standard Deviation & Mean $\mathrm{R}_{\mathrm{a}}$ & Standard Deviation \\
\hline Lisa & 0.07 & 0.02 & 0.38 & 0.16 \\
\hline
\end{tabular}

$0.02 \mu \mathrm{m})$. The mean value of the roughness test for the apatite surface was $0.38 \mu \mathrm{m}$ (SD, $0.16 \mu \mathrm{m})$. These results are shown in Table 2. Titanium samples treated chemically exhibited significantly rougher surfaces compared with the original surface $(P=$ $0.0002)$. This rough surface layer encourages bony ingrowth into its porous structure to provide a mechanical fixation of the implant to the surrounding bone. ${ }^{6}$

A macroporous titanium surface layer would induce apatite ingrowth into its porous structure after the chemical treatment. The stress at the bone-implant interface is, therefore, expected to decrease by designing the roughness of the apatite coating to gradually decrease as a function of depth toward the titanium substrate.

\section{Bonding Strength of the Coating Layer}

The mean value of the scratch test for the plasma-sprayed apatite layers was $160 \mathrm{mN}$ (SD, $15 \mathrm{Mn}$ ). Their mean thickness was $20 \mu \mathrm{m}$. The mean value of the scratch test for the chemical apatite layers was $450 \mathrm{mN}$ (SD, 23 $\mathrm{mN})$. Their mean thickness was 15 $\mu \mathrm{m}$. The statistic test showed ( $P$ $<0.005)$ that the bonding strength of hydroxyapatite coatings formed by chemical treatment to the titanium substrate is higher than the plasmasprayed hydroxyapatite coatings. The apatite coating formed in the SBF bonds chemically to the $\mathrm{Ti}$ substrate through the hydrated titanium and titanium oxide layers. The heat treatment $\left(600^{\circ} \mathrm{C}\right)$ of the alkali-treated $\mathrm{Ti}$ samples before soaking in SBF induces the apatite formation and increases the adhesion of the apatite layer to the substrate.

This indicates that the chemical apatite coatings bond tighter to the titanium substrate than the plasmasprayed apatite. This provides a long- term bone-implant fixation attained by chemical integration through the apatite layer. On the other hand, the absence of any chemical link between the plasma-sprayed apatite and the titanium substrate leads to a limited adhesion between the coating to the implant. This plasma-sprayed apatite layer shows a porous structure that is very susceptible to contamination to bacteria.

Another disadvantage of the plasma-spray method is related to the high temperature used $\left(8000^{\circ} \mathrm{C}\right)$. Hydroxyapatite is thermally unstable during cooling (from 8000 to $25^{\circ} \mathrm{C}$ in a very short lapse of time) after plasmasprayed deposition on the titanium substrate, thus producing amorphous calcium phosphate phases. As it is known, this amorphous phases and even phases as tetracalcium and tricalcium phosphates, which are also formed during cooling, dissolve faster than crystalline hydroxyapatite, thus leading to mechanical disintegration of the coating and loosening of the implant fixation. ${ }^{7}$ On the other hand, the Kokubo method allows for control of the chemical composition and crystallinity of the apatite coating as well as of its physical and mechanical properties.

\section{Conclusions}

The heat and chemical treatments produced a bioactive hydroxyapatite layer on a titanium surface along its surface morphology. The apatite surface did not show a lower roughness than the titanium substrate surface. This indicates that the apatite coating not only provides a chemical integration with bone, but also encourages bony ingrowth into its porous structure to provide a mechanical fixation of the implant. The apatite layer formed chemically showed higher bonding strength to the titanium substrate than the plasma-sprayed apatite. The chemically made apatite coating is expected to provide a long-term implant-bone fixation.

\section{Disclosure}

The authors claim to have no financial interest in any company or any of the products mentioned in this article.

\section{REFERENCES}

1. de Groot K, Geesink R, Klein CP, et al. Plasma sprayed coatings of hydroxylapatite. J Biomed Mater Res. 1987;21: 1375-1381.

2. Yang CY, Lin RM, Wang BC, et al. In vitro and in vivo mechanical evaluations of plasma-sprayed hydroxyapatite coatings on titanium implants: the effect of coating characteristics. J Biomed Mater Res. 1997;3:335-345.

3. Kokubo T, Miyaji F, Kim HM, et al. Formation of bone-like apatite layer on chemically treated titanium metals. J Am Ceram Soc. 1996;79:1127-1129.

4. Manero JM, Salsench J, Nogueras $J$, et al. Growth of bioactive surfaces on dental implants. Implant Dentistry. 2002; 11:170-175.

5. Takadama H, Kim HM, Kokubo T, et al. An x-ray photoelectron spectroscopy study of the process of apatite formation on bioactive titanium metal. J Biomed Mater Res. 2001;55:185-193.

6. Kim HM, Kokubo T, Fujibayashi S, et al. Bioactive macroporous titanium surface layer on titanium substrate. J Biomed Mater Res. 2000;52:553-557.

7. Park E, Condrate SR, Hoelzer DT, et al. Interfacial characterisation of plasmaspray coated calcium phosphate on Ti6Al4V. J Mater Sci Med. 1998;9:643649.

Reprint requests and correspondence to: Joaquim Nogueras-Bayona, PhD Universitat de Barcelona Facultat d'Odontologia Campus de Bellvitge

C/Feixa Llarga s/n

08907 L'Hospitalet de Llobregat Barcelona, Spain

E-mail: quimnogueras@ub.edu 


\section{Abstract Translations [German, Spanish, Portugese, Japanese]}

$\boldsymbol{A U T O R}(\boldsymbol{E N}): \quad$ Joaquim Nogueras-Bayona, $\mathrm{PhD}^{*}$, Francesc Javier Gil, PhD**, Joan Salsench, $\mathrm{PhD}^{* * *}$, Jordi Martinez-Gomis, PhD****. * A.O. Professor, Fachbereich Prothetik, zahnmedizinische Fakultät, Universität Barcelona, Barcelona, Spanien. ** Professor, Abteilung für Materialforschung und Metallurgie, ETSEIB, technische Universität von Katalonien, Barcelona, Spanien. *** Professor, Fachbereich Prothetik, zahnmedizinische Fakultät, Universität Barcelona, Barcelona, Spanien. **** A.O. Professor, Fachbereich Prothetik, zahnmedizinische Fakultät, Universität Barcelona, Barcelona, Spanien. Schriftverkehr:Joaquim Nogueras-Bayona, PhD, Universitat de Barcelona, Facultat d'Odontologia, Campus de Bellvitge, C/ Feixa Llarga s/n, 08907 L'Hospitalet de Llobregat, Spanien.eMail: quimnogueras@ub.edu

\section{Rauheit und Bindefähigkeit bioaktiver Apatitbeschichtung auf Zahnimplantaten}

ZUSAMMENFASSUNG: Zielsetzung: Innerhalb dieser Studie wurden die Rauheit und Bindefähigkeit einer chemisch hergestellten Apatitbeschichtung im Vergleich zu einer Titanoberfläche und einem mit Plasma besprühten Apatit untersucht. Methoden und Materialien: Reine Titanplatten wurden durch Hitzeinwirkung und Chemikalieneinsatz vorbereitet, so dass auf den Oberflächen kristallines Apatit aufgebracht werden konnte. Durch ein die Rauheit der Oberfläche abprüfendes Testmedium wurde die Oberflächenrauheit der ursprünglichen Titanimplantate und apatitbeschichteten Implantate analysiert. Um Vergleichswerte bezüglich der Adhäsion der chemischen Apatitbeschichtung auf dem Titanimplantatkörper zu der mit Plasma besprühten Oberflächenbeschichtung zu erhalten, wurde ein Kratztest durchgeführt. Ergebnisse: Eine einfache chemische Methode führte zur Ausbildung einer dichten, knochengewebsartigen Apatitbeschichtung auf der Oberfläche des Titanimplantats. Der Test zur Überprüfung der Oberflächenrauheit ergab eine Erhöhung der Oberflächenrauheit durch chemische Apatitbeschichtung. Im Kratztest erwies sich die Bindefähigkeit der chemisch hergestellten Apatitbeschichtung zur Titanbasis als höher als die entsprechende Bindefähigkeit der mit Plasma besprühten Apatitbeschichtung. Schlussfolgerungen: Die durch chemische Weiterbehandlung hervorgerufene Apatitbeschichtung wies gegenüber dem Titansubstrat gleiche Rauheitsgrade auf. Die Bindefähigkeit der chemischen Apatitbeschichtung an die Titansubstanz war auch weitaus höher als die des mit Plasma besprühten Apatits. Es ist davon auszugehen, dass diese chemisch hergestellte Apatitoberfläche für eine langfristige Fixierung zwischen Implantat und Kochen sorgen kann.

SCHLÜSSELWÖRTER: Biomaterialien, Apatit, Titan, Kratztest

La aspereza y solidez de pegado de una capa de apatita bioactiva en implantes dentales

ABSTRACTO: Propósito: Este estudio examinó la aspereza y solidez de pegado de la capa de apatita hecha con químicos en comparación con la superficie de titanio y la apatita rociada con plasma. Métodos y materiales: Las placas de titanio comercialmente puro fueron calentadas y tratadas químicamente para depositar apatita cristalina en la superficie. La aspereza de la superficie de titanio de las muestras originales y la superficie de apatita fue analizada en un analizador de la aspereza de la superficie. Se usó una prueba rayado se usó para comparar la adhesión de la capa de apatita química al titanio con la adhesión de una capa rociada con plasma.

Resultados: Se formó una capa de apatita con densidad similar al hueso sobre la superficie del titanio a través de un método químico simple. La prueba de aspereza de la superficie demostró que el revestimiento de la apatita química aumentó la aspereza de las muestras. La prueba de rayado demostró que la solidez de pegado de los revestimientos de apatita creados con químicos al substrato de titanio era más alta que los revestimientos de apatita rociados con plasma. Conclusiones: La capa de apatita producida con el tratamiento químico no mostró una menor aspereza que el substrato de titanio. Este capa química de la apatita también se pegó mejor al titanio que la apatita rociada con plasma. Este revestimiento de la apatita creado químicamente se espera que proporcione una fijación del hueso al implante de largo plazo.

PALABRAS CLAVES: biomateriales, apatita, titanio, prueba de rayado. 
AUTOR(ES): Joaquim Nogueras-Bayona, $\mathrm{PhD}^{*}$, Francesc Javier Gil, $\mathrm{PhD} * *$, Joan Salsench, $\mathrm{PhD} * * *$, Jordi Martinez-Gomis, PhD****. * Professor Associado, Seção de Prostodontia, Faculdade de Odontologia, Universidade de Barcelona, Barcelona, Espanha. ** Professor, Departamento de Materiais, Ciência e Metalurgia, ETSEIB, Universidade Técnica da Catalunha, Barcelona, Espanha. *** Professor, Seção de Prostodontia, Faculdade de Odontologia, Universidade de Barcelona, Barcelona, Espanha. ****Professor Associado, Seção de Prostodontia, Faculdade de Odontologia, Universidade de Barcelona, Barcelona, Espanha. Correspondência para: Joaquim NoguerasBayona, PhD, Universitat de Barcelona, Facultat d'Odontologia, Campus de Bellvitge, C/ Feixa Llarga s/n, 08907 L'Hospitalet de Llobregat, SPAIN. E-mail: quimnogueras@ub.edu

\section{Aspereza e Força Adesiva de Camada de Apatita Bioativa em Implantes Dentários}

RESUMO: Objetivo: Este estudo examinou a aspereza e a força adesiva da camada de apatita produzida quimicamente em comparação com a superfície de titânio e a apatita pulverizada por plasma. Métodos e Materiais: Placas de titânio comercialmente puro foram tratados com calor e quimicamente para depositar apatita cristalina em sua superfície. A aspereza da superfície de titânio das amostras originais e a superfície de apatita foram analisadas por um aparelho de ensaio de superfície de aspereza. Um teste esclerométrico foi usado para comparar a adesão da camada de apatita química ao titânio com a adesão de uma camada pulverizada com plasma. Resultados: Uma camada densa de apatita óssea foi formada na superfície do titânio por um simples método químico. O teste de aspereza da superfície mostrou que a camada de apatita química aumentou a aspereza das amostras. O teste esclerométrico mostrou que a força adesiva das camadas de apatita produzida quimicamente ao substrato de titânio foi maior que as camadas de apatita pulverizadas com plasma. Conclusões: A camada de apatita produzida por tratamento químico não mostrou aspereza menor que o substrato de titânio. Esta camada de apatita química também aderiu mais fortemente ao titânio do que a apatita pulverizada com plasma. Espera-se que esta camada de apatita produzida quimicamente proporcione uma fixação de longo prazo do osso de implante.

PALAVRAS-CHAVE: Biomateriais, apatita, titânio, teste esclerométrico

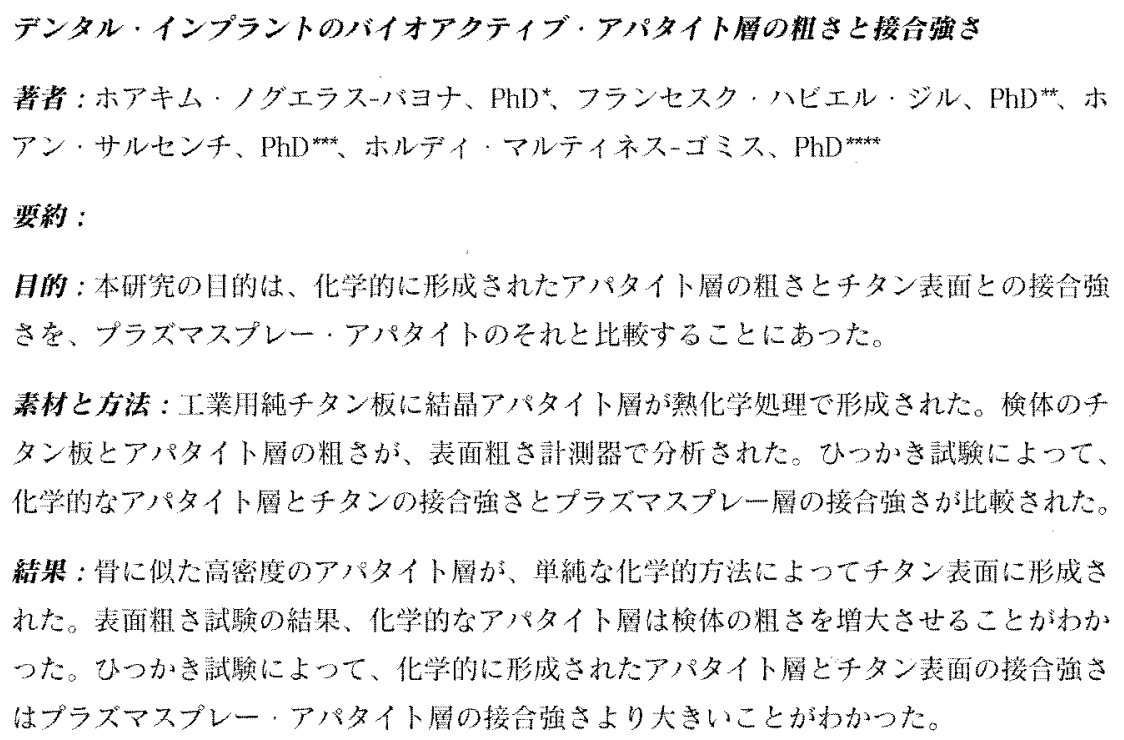

